\begin{tabular}{lc}
\hline CURRENT & ISSN: 0973-4929, Vol. 15, №. (1) 2020, Pg. 01-04 \\
WORLD & Current World Environment
\end{tabular}

ENVIRONMENT

www.cwejournal.org

\title{
Environmental Changes during COVID-19 Lockdown: Future Implications
}

\author{
UMESH CHANDRA KULSHRESTHA
}

School of Environmental Sciences, Jawaharlal Nehru University, New Delhi.

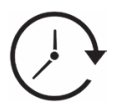

\section{Article History}

Published on: 7 April 2020

Dear Readers,

In a way the spread of COVID-19 has forced the globe to halt all outdoor human activities for the longest period in the memories of the present population of this planet. This lockdown will probably be marked in history forever. Nevertheless, this shutdown is a rejuvenation of the Earth, environment and human health systems. Despite the sudden changes to the daily behaviour of humans, our surrounding ecological systems are enjoying holistic and positive changes. This is a kind of Holistic treatment of ecological system as the shut down has multiple positive effects. The implications and outcomes of the prohibition of outside activities is different for different aspects of the environment, as described below-

\section{A. Physical Environmental Aspect}

Halting outside movements has stopped all types of transportation (aircrafts buses, cars, trucks etc.) which has controlled emissions of pollutants. China has witnessed a drastic reduction in NOx during the Coronavirus lockdown (2020) as compared to the values last year (2019). Eastern and central China areas showed a significant reduction $(10-30 \%)$ in $\mathrm{NO}_{2}$ levels. ${ }^{1} \mathrm{CBCB}$ data showed more than $50 \%$ reduction in $\mathrm{PM}_{10}$ and $\mathrm{PM}_{2.5}$ levels. ${ }^{2-3}$ According to reports in the United States of America, Coronavirus shutdown has resulted in a huge decline in pollution over major cities such as Los Angeles, Seattle, New York, Chicago and Atlanta etc. ${ }^{4}$

On average, a Jumbo Boeing 747 consumes around 150,000 litres fuel in a 10 hrs flight. Cumulatively around 400 billion litres of fuel is consumed annually by the commercial flights. ${ }^{5}$ Additionally, aircrafts fly at 8-13 km height from ground kevel emitting huge amount of $\mathrm{NOx}, \mathrm{CO}_{2}$ and various hydrocarbons. These emissions affect radiative forcing and stratospheric ozone. The aircraft contrails mostly seen in the temperate

CONTACT Umesh Chandra Kulshrestha $\$ umeshkulshrestha @gmail.com 9 School of Environmental Sciences, Jawaharlal Nehru University, New Delhi.

\section{(c) (i)}

(C) 2020 The Author(s). Published by Enviro Research Publishers.

This is an Open Access article licensed under a Creative Commons license: Attribution 4.0 International (CC-BY).

Doi: http://dx.doi.org/10.12944/CWE.15.1.01 
regions cause warming of the Earth's atmosphere. ${ }^{6}$ Similarly, a large amount of pollutants from road transport emissions as well as fuel and operational emissions from the industrial sector are controlled due to complete shutdown.

This will be a healing dose for climate change, ozone depletion, human health, brown haze etc.

\section{B. Social Environmental Aspect}

The followings are the major social change observations during the COVID-19 lockdown-

\section{Family Health}

Being forced stay home has brought the family members together. They are forced to talk, eat and play together every day, which was not possible for some families due to work and various responsibilities when one was scheduled to go early and come back during odd hours when children were sleeping. It was heard sometimes that some of the children could meet their fathers weekly or fortnightly due to father's over business. Hence, the lockdown is good for family health.

\section{E-Education}

The lockdown in the middle of the semester has interrupted the regular educational session. Primary and secondary school students are most affected because most of them are cut off from the academic interactions with their teachers. However, higher education students are able to engage with their teachers and professors. Several universities have asked their faculty to keep giving online classes and supplying reading material through emails. In a nutshell, for more mature students, the traditional class room education is turned into e-class room education system. I foresee it as a global turning point for adopting this new 'e-Education'system and 'Work from Home'cultures which are being endorsed by institutions and individuals.

The e-education will have impact on research and it's procedures. During e-education, one cannot accumulate practical experience of real laboratory work like handling of apparatus and instruments etc. Hence, the degree holder of science by e-education will be useful only for teaching, online demonstrations, model creation, online material designing and modeling etc. Most colleges and universities will be deprived of good students and funds, which may result in abandoned physical campuses. My analysis is that the number of excellent research centers will be reduced, leading to reduced quality and quantity of formal research. However, the publications of traditional researchers will be less effective than the ideas given by a layman through online YouTube videos and Tik Tok platforms. Funding patterns for research as well as the priorities for future research areas will be changed.

\section{Work From Home (WFH)}

A holistic approach of engagements: As I mentioned above, the lock down has forced us to work from home. This is a big change for future social engineering. This is going to be more and more acceptable and popular in all segments of the society. WFH has several advantages over traditional work culture. ${ }^{7}$

WFH is kind of holistic approach of life. It has the following advantages-

- When you are at home every time, you take complete sleep, a basic need for good health and peaceful working. It is believed that a good sleep enhances immunity. ${ }^{8-9}$

- You save time of travel to office to and fro, that gives you extra hours of working which means more efficiency and productivity. Secondly, you save fuel and help in controlling air pollution. Thirdly, there is no stress of travelling which means more efficiency.

- WFH allows you to take good care of children and old aged parents. However, the WFH has some side effects such as partial adherence with schedule, delivery excuses, local disturbance (indoor and outdoor), boredom, lack of self-hygiene, domestic violence etc. 


\section{Social Engineering}

The fear of COVID-19 spread is forcing for physical distancing as people are self-quarantined. This is developing new habits of survival and new approach of interaction with nears and dears. It is also forcing us to modify the life style. The social distancing is really creating gaps between friends and relatives. However, the mobile phones and internet are keeping people close to each other. Slowly, people are adapting to stay home and develop new habits to keep themselve engaged in professional work vis-a-vis domestic work. Many are experiencing behavioural changes towards spouse and children. Survilence is also being during the lockdown which will reveal the conversations and contacts of individuals. This may have future repurcations for the govenments. The outcome of this social engineering is unpredictable.

\section{Sustainability and Rejuvenation of Earth System}

The lockdown is a highly sustainable approach. Now, the flights are grounded resulting in reduction of noise and injection of tropospheric and stratospheric pollutants. Ozone layer is also reported to be healing. ${ }^{10} \mathrm{The}$ road transport and factories are also closed and hence, the emissions of air pollutants are reduced. After the lockdown, a variety of birds are seen in the localities. Due to lock down, the resources are being consumed in a limited manner. People have realized that their survival needs are very less but for status in the society they were wasting the resources. I would say that the lockdown is teaching us the practical lessons how to achieve the Sustainable Development Goals (SDGs). ${ }^{11}$ The global shutdown is allowing the planet to heal and rejuvenate itself against the torture of Homo sapiens of twentieth century.

\section{New Opportunities for Creativity and Talent}

The lockdown has proved that people are highly creative. Their hidden talent is getting opportunity of expression and exhibition. The school and college education kept them too busy to pursue their hobbies. I am witnessing that the people are writing poetry, making cartoons, preparing new dishes in kitchen, developing web sites, singing songs, playing music etc. along with the online classes. I mean that people are able to use the time for their hobbies and education together.

\section{Spiritual Environmental Aspect}

During the lockdown, staying at home and working from home has forced us to opt all the alternate methods for keeping engaged. One of the best methods is meditation and Yoga that give peace and good health. We are not able to go to parks for physical exercise. Performing yoga, meditation and prayers regularly rejuvenates our body in terms of enhancing our immunity system, concentration of mind and confidence levels. ${ }^{12}$ Spiritual development is essential for humanity and positive personality development. There are a number of online yoga classes given by the experts, which is proving the utilization of lockdown time fruitfully. I guess a more positive behavior of public after the lockdown. If it happens, that will be a relief to the governments. A peaceful nation can make significant growth due to savings in no-war and no-crime state.

\section{References}

1. Coronavirus lockdown reduces China's air pollution NASA images. https://economictimes.indiatimes. com/magazines/panache/coronavirus-lockdown-reduceschinas-air-pollution-nasa-images-showdrop-in-airborne-no2levels/articleshow/74440991.cms?from=mdr). The Economic Times. Retrived on April 5, 2020.

2. CPCB.2020. https://app.cpcbccr.com/AQI_India/. Retrived on April 5, 2020.

3. Singh and Kulshrestha. 2020. Changes in Air Quality Index (AQI) of $\mathrm{PM}_{2.5}, \mathrm{NO}_{2}$ and $\mathrm{O}_{3}$ in Delhi City during Lockdown Period due to Pandemic COVID-19. (Communicated).

4. Plumer B. and Popovich N. 2020.Traffic and Pollution Plummet as U.S. Cities Shut Down for Coronavirus. https://www.nytimes.com/interactive/2020/03/22/climate/coronavirus-usa-traffic.html. Retrived on April 5, 2020.

5. Statica.com. 2020. https://www.statista.com/statistics/655057/fuel-consumption-of-airlinesworldwide/. 
Retrived on April 5, 2020.

6. The ozone hole. 2020. http://www.theozonehole.com/airtraffic.htm. Retrived on April 5, 2020.

7. Verma K and Kulshrestha.U. 2018. Feasible Mitigation Options for Air Pollution and Traffic Congestion in Metro Cities. J Indian Geophysical Union, 22(2), 212-218.

8. Besedovsky L, Lange T, and Born J. 2012. Sleep and immune function. Pflugers Arch. 463, 121-137. doi: 10.1007/s00424-011-1044-0.

9. Dimitrov S, et al. 2019. Gas-coupled receptor signaling and sleep regulate integrin activation of human antigen-specific T cells. J Experimental medicine, 216, 517-526. doi.org/10.1084/jem.20181169.

10. Ozone layer is healing amidst coronavirus gloom ozone cover above Antarctica records substantial recovery. 2020. https://www.financialexpress.com/lifestyle/science/ozone-layer-ishealing-amidstcoronavirus-gloom-ozone-cover-above-antarctica-records-substantialrecovery/1911386/. Retrived on April 5, 2020.

11. UN2020. Sustainable Development Programme. Knowledge Plateform. https://sustainabledevelopment. un.org/. Retrived on April 5, 2020.

12. Benefits of meditation. https://eocinstitute.org/meditation/meditation-increases-feelings-ofvitality-andrejuvenation/.Retrived on April 5, 2020. 